\title{
Physico-chemical properties, rheological characteristics, and storage stability of cold-break processed tomato paste enriched with rice flour
}

\author{
${ }^{1}$ Alqahtani, N., ${ }^{2}$ Abdulsalam, N., ${ }^{2}$ Abduljawad, E., ${ }^{1}$ Alnemr, T. and ${ }^{3, *}$ Ali, S. \\ ${ }^{1}$ Department of Food and Nutrition Sciences, College of Agricultural and Food Sciences, King Faisal \\ University, Al-Ahsa 31982, Saudi Arabia \\ ${ }^{2}$ Department of Food and Nutrition, King Abdulaziz University, Jeddah 21589, Saudi Arabia \\ ${ }^{3}$ Department of Food Science, Faculty of Agriculture (Saba Basha), Alexandria University, Alexandria \\ 21531, Egypt
}

\begin{abstract}
Article history:
Received: 27 February 2021

Received in revised form: 5 April 2021

Accepted: 13 June 2021

Available Online: 23 January 2022

\section{Keywords:}

Tomato paste,

Rice flour,

Physico-chemical properties, Rheological behaviour

\section{DOI:}

https://doi.org/10.26656/fr.2017.6(1).134
\end{abstract}

\begin{abstract}
Tomato pastes (TP) enriched with rice flour (RF) were evaluated for physico-chemical properties, rheological characteristics, and storage stability. TP was prepared from fresh tomato fruits with the addition of RF at the levels of 2,4 , and $6 \%(\mathrm{w} / \mathrm{w})$ using the cold break method and stored for 12 weeks at ambient temperature. Insignificant changes in the chemical compositions of TP samples were observed. Pastes contained RF revealed higher $L^{*}$ values than control. During storage, $\mathrm{L}^{*}$ and $\mathrm{a}^{*}$ values of TP decreased, while $\mathrm{b}^{*}$ values increased. The $\mathrm{a}^{*} / \mathrm{b}^{*}$ ratio of TP contained RF were approximately stable during storage and were at acceptable levels. Samples contained RF showed higher $\mathrm{pH}$ and total soluble solids (TSS) with lower ascorbic acid content (AAC), acidity, and Bostwick than control. The AAC and $\mathrm{pH}$ decreased, whereas acidity, TSS, and Bostwick increased during storage. The paste containing 4\% RF showed the highest sensory scores among all tested samples at zero time and during storage. Such findings may be helpful particularly for the low-income population as it is a low-cost preservation method.
\end{abstract}

\section{Introduction}

Tomato (Solanum lycopersicum) is the most consumed vegetable crop around the world with global production of 182 million tonnes (FAO, 2018). It is characterized by its unique colour, flavour, taste, antioxidants content, and other valuable nutrients. Tomato is an important part of the human diet that can be consumed either fresh or processed; it is mainly used as an indispensable component in various types of foods (Banat et al., 2002). Tomato is an excellent source of antioxidants such as carotenoids (mainly $\beta$-carotene and lycopene), flavonoids (particularly quercetin and kaempferol), vitamin $\mathrm{C}$, and phenolic compounds besides minerals, organic acids, and amino acids especially glutamic (Giovanelli and Paradiso, 2002; Koh et al., 2012; Olaniran et al., 2015). Lycopene, particularly in processed tomatoes, has been found to protect against prostate cancer. Moreover, tomato is a good source of fibre, which may improve the efficiency of the digestive system and prevent colon diseases. The regular consumption of tomatoes or their products could prevent prostate, gastrointestinal, and epithelial cells cancers besides cardiovascular disease (Donkor et al., 2015).

The perishable nature of tomatoes and the insufficient storage facilities may increase the postharvest losses, which can be avoided by processing the surplus produce (Abano et al., 2012). Therefore, keeping the nutritional value and sensory quality of tomatoes by improving processing conditions is of vital importance. Tomato may be processed into juice, soup, sauce, salsa, paste, ketchup, and puree. Nowadays, tomato paste became one of the most consumed foods in several countries not only for its desirable taste, flavour, and aroma but also for the content of both nourishing components and natural antioxidants. The increasing demand for tomato paste is related to its use as a starting material in various convenience foods such as pizza and pasta sauces (Koh et al., 2012).

In fact, tomato pastes are made through a series of processing steps including initial thermal treatment followed by pulping, filtering, evaporation, and pasteurization. However, there are two types of thermal treatments applied in tomato paste processing: (1) hot 
break processing in which tomatoes are heated up to $95^{\circ} \mathrm{C}$; this procedure preserves viscosity with some loss in flavour; and (2) cold break processing in which tomatoes are heated up to $65^{\circ} \mathrm{C}$; this method maintains flavour with some loss in viscosity. After thermal treatment, tomatoes are subjected to a process called pulping where tomatoes are forced to pass through strainers of various sizes. The obtained product is evaporated at a specific temperature for a certain time depending on the required viscosity of the final product. After that, the product is sterilized at $100^{\circ} \mathrm{C}$ for $3-5 \mathrm{~min}$, cooled, and packaged into aseptic containers. However, the final product of tomato paste contains $21-37 \%$ TSS according to manufacturing requirements (Koh et al., 2012).

The quality of tomato paste depends on the quality of the raw materials, processing conditions, and storage (Farahnaky et al., 2010). However, the consumer is mainly interested in colour, consistency, flavour, and composition of tomato paste. Accordingly, tomato paste was processed using the cold break method to maintain flavour, but the texture may be affected. Therefore, it is urgent to find a suitable thickening agent to improve the texture properties of the paste. Rice flour (RF) has unique properties, small granule morphology, accepted odour, smooth taste, hypoallergenic properties, low levels of sodium, and easily digestible carbohydrates (Yang et al., 2016). Moreover, RF can be properly employed as a thickening agent in the production of high viscosity foods (Lopez et al., 2004; Ye et al., 2016). Generally, there are no more studies on the evaluation of using RF to improve the texture properties of tomato paste. Consequently, we suggested the possibility of using $\mathrm{RF}$ as a thickening agent to improve the consistency and maintain the quality of tomato paste. Accordingly, the objective of this study was to explore the rheological behaviour, physico-chemical properties, sensory characteristics, and storage stability of tomato paste enriched with RF.

\section{Materials and methods}

\subsection{Raw materials}

Tomato fruits were procured from the local market, Benha city, Egypt. Rice flour was obtained from Tiba for starch and glucose manufacturing Co., Egypt.

\subsection{Preparation of samples}

Tomato paste samples were prepared according to the method reported by Koh et al. (2012) and Olaniran et al. (2015). The freshly harvested, ripe, and deep red coloured tomato fruits were washed, crushed, and heated at $60^{\circ} \mathrm{C}$ (cold break). The tomatoes were then pulped and refined using strainers of various sizes (1.2,
0.8 and $0.4 \mathrm{~mm}$ ) to remove seeds, skin, and large coarse pieces and to get the uniform pulp. The tomato paste was concentrated to $36-38^{\circ} \mathrm{Bx}$ through three stages, the first was performed at $60-65^{\circ} \mathrm{C}$, the second was carried out at $65-70^{\circ} \mathrm{C}$, and the last was performed at $70-75^{\circ} \mathrm{C}$ under vacuum. $\mathrm{RF}$ was added gradually during the first stage to prepare various treatments i.e. $0 \%\left(\mathrm{~T}_{0}\right), 2 \%\left(\mathrm{~T}_{1}\right), 4 \%$ $\left(\mathrm{T}_{2}\right)$, and $6 \%\left(\mathrm{~T}_{3}\right)$. The tomato pastes were pasteurized at $105^{\circ} \mathrm{C}$ for $3-5$ mins, cooled to $35^{\circ} \mathrm{C}$, packaged into aseptic plastic bags, and placed in the dark at room temperature for further estimations.

\subsection{Chemical composition}

Proximate analysis of tomato paste samples was carried out according to the method described by AOAC (2006).

\subsection{Colour parameters}

The colour attributes of tomato paste samples were measured using a colour reader (CR-10, Konica Minolta Sensing Inc., Japan). The results were expressed as L* (lightness; $0=$ black, $100=$ white $), a^{*}\left(+a^{*}=\right.$ redness, $\mathrm{a}^{*}=$ greenness $)$, and $\mathrm{b}^{*}\left(+\mathrm{b}^{*}=\right.$ yellowness, $-\mathrm{b}^{*}=$ blueness) values. In addition, the $\mathrm{a}^{*} / \mathrm{b}^{*}$ ratio was determined to specify the quality of tomato paste, which was considered unacceptable when the value becomes less than 1.80 (Basak, 2018; Ali et al., 2020).

\subsection{Ascorbic acid content}

The ascorbic acid content was determined according to the methods of AOAC (2006).

\subsection{Total titratable acidity and $\mathrm{pH}$}

The total titratable acidity was determined in terms of citric acid according to the method reported by Ganje et al. (2016). The $\mathrm{pH}$ of tomato paste samples was measured using a digital $\mathrm{pH}$-meter (Denver Instruments Co., USA) at the temperature of $25^{\circ} \mathrm{C}$. Before determinations, the device was calibrated using buffer solutions with $\mathrm{pH}$ of 7.0 and 4.0 .

\subsection{Total soluble solids and Bostwick consistency}

The total soluble solids were estimated using an Abbe refractometer (AR4, Kruss, Germany) at the temperature of $25^{\circ} \mathrm{C}$ according to Jafari et al. (2018). The consistency of tomato paste samples was measured using Bostwick consistometer (CSC Company Inc., USA) according to the method described by Jafari et al. (2018).

\subsection{Sensory evaluation}

Organoleptic properties of tomato paste samples were evaluated using a 10-member panel. The samples 
were coded, and the panellists were asked to evaluate the samples in terms of colour, flavour, texture, and overall acceptability through the nine-point hedonic scale (from like extremely $=9$ to dislike extremely $=1$ ) according to Olaniran et al. (2015).

\subsection{Statistical analysis}

Analyses of tomato paste samples were carried out in triplicates. The results were statistically analysed using analysis of variance (ANOVA) with a statistical package for the social sciences (SPSS Inc., Chicago, USA).

\section{Results and discussion}

\subsection{Chemical composition of tomato paste samples}

The proximate analysis of tomato paste samples at different levels of RF additions is given in Table 1. The moisture content of tomato pastes ranged from 73.08 to $69.25 \%$. The pastes contained RF showed lower moisture content than the control sample. In fact, the moisture content of tomato pastes decreased insignificantly $(\mathrm{P}>0.05)$ by increasing the level of RF addition which could be attributed to the lower moisture content of RF. The protein and fat content of tomato pastes ranged from 3.68 to 3.82 and 0.41 to $0.48 \%$, respectively. It was observed that the protein and fat content of tomato pastes increased slightly by increasing the level of RF addition, which could be related to the chemical composition of RF. The carbohydrate content of tomato pastes varied between 18.23 to $21.92 \%$. The pastes contained RF revealed higher carbohydrate content than the control sample. The carbohydrate content of tomato pastes increased significantly $(\mathrm{P}<$ 0.05 ) by increasing the amount of RF. Kaushal et al. (2012) reported that RF is an important source of carbohydrate and protein with higher nutritional quality. Ash and fibre content of tomato paste samples ranged from 2.31 to 2.55 and 1.92 to $2.03 \%$, respectively. However, a slight decrease in the ash and fibre content of tomato paste samples was noticed by increasing the level of RF addition. The results of the chemical composition of tomato paste in the current study were similar to those obtained by other researchers (Padovani et al., 2007; Eke -Ejiofor, 2015).

\subsection{Colour parameters}

Colour is considered one of the most important quality parameters of fruits and vegetables and their products. The measurements of colour attributes of stored tomato paste samples with different ratios of RF are displayed in Table 2. It was observed that $L^{*}$ and $b^{*}$ values of freshly processed tomato pastes increased significantly $(\mathrm{P}<0.05)$, while $\mathrm{a}^{*}$ values decreased insignificantly $(\mathrm{P}>0.05)$ by increasing the level of $\mathrm{RF}$ addition, which could be related to the dilution effect of $\mathrm{RF}$ on the colour parameters of the pastes i.e. it increases the light colour. The values of colour parameters of freshly processed tomato pastes in the current study were similar to those reported by Kelebek et al. (2017). It could be noticed that $\mathrm{L}^{*}$ values of tomato paste samples decreased significantly $(\mathrm{P}<0.05)$ from $25.86-29.13$ to $23.50-27.88 \%$ after 0 and 80 days of storage, respectively. Likewise, $a^{*}$ values of tomato paste samples revealed a significant $(\mathrm{P}<0.05)$ decrease from $34.13-35.26$ to $33.06-33.91 \%$ after 0 and 80 days of storage, respectively. On contrary, $b^{*}$ values increased insignificantly $(\mathrm{P}>0.05)$ from $14.91-17.06$ to $17.26-$ $17.43 \%$ after 0 and 80 days of storage, respectively. Generally, it could be observed that tomato pastes contained 4 and $6 \%$ RF were more stable during storage than control and the sample contained $2 \% \mathrm{RF}$ regarding colour parameters.

The $\mathrm{a}^{*} / \mathrm{b}^{*}$ ratio has been used as a quality specification for tomato products (Kelebek et al., 2017). As mentioned in Table 2, the values of $\mathrm{a}^{*} / \mathrm{b}^{*}$ ratio of the control sample decreased significantly $(\mathrm{P}<0.05)$ from 2.36 to $1.96 \%$ after 0 and 80 days of storage, respectively. On the other hand, $a^{*} / b^{*}$ ratio values of the pastes contained RF were approximately stable during the storage period. Tomato pastes with $\mathrm{a} / \mathrm{b} *$ ratio values below 1.80 are considered unacceptable (Basak, 2018). However, all samples in the current study revealed acceptable values of the $a^{*} / b^{*}$ ratio during the storage period. The changes in colour parameters of tomato paste

Table 1. Proximate analysis of tomato pastes samples at different levels of rice flour.

\begin{tabular}{lcccc}
\hline \multicolumn{1}{c}{ Parameters } & \multicolumn{4}{c}{ Treatments } \\
\cline { 2 - 5 } \multicolumn{1}{c}{$\mathrm{T}_{0}$} & $\mathrm{~T}_{1}$ & $\mathrm{~T}_{2}$ & $\mathrm{~T}_{3}$ \\
\hline Protein & $3.68 \pm 0.09^{\mathrm{b}}$ & $3.72 \pm 0.04^{\mathrm{ab}}$ & $3.77 \pm 0.02^{\mathrm{ab}}$ & $3.82 \pm 0.05^{\mathrm{a}}$ \\
Fat & $0.41 \pm 0.01^{\mathrm{c}}$ & $0.43 \pm 0.01^{\mathrm{bc}}$ & $0.45 \pm 0.02^{\mathrm{b}}$ & $0.48 \pm 0.01^{\mathrm{a}}$ \\
Moisture & $73.08 \pm 1.26^{\mathrm{a}}$ & $71.74 \pm 1.52^{\mathrm{ab}}$ & $70.49 \pm 1.23^{\mathrm{ab}}$ & $69.25 \pm 1.77^{\mathrm{b}}$ \\
Ash & $2.55 \pm 0.07^{\mathrm{a}}$ & $2.46 \pm 0.08^{\mathrm{ab}}$ & $2.39 \pm 0.08^{\mathrm{bc}}$ & $2.31 \pm 0.06^{\mathrm{c}}$ \\
Dietary fiber & $2.03 \pm 0.01^{\mathrm{a}}$ & $1.99 \pm 0.04^{\mathrm{ab}}$ & $1.96 \pm 0.02^{\mathrm{bc}}$ & $1.92 \pm 0.05^{\mathrm{c}}$ \\
Carbohydrate & $18.23 \pm 0.46^{\mathrm{c}}$ & $19.47 \pm 0.53^{\mathrm{bc}}$ & $20.71 \pm 0.77^{\mathrm{ab}}$ & $21.92 \pm 0.82^{\mathrm{a}}$ \\
\hline
\end{tabular}

Values are presented as mean \pm standard deviation, $\mathrm{n}=3$. Values with different superscript within the same row are significantly different $(\mathrm{P}<0.05)$. 
Table 2. Changes of colour parameter in tomato pastes during storage.

\begin{tabular}{cccccc}
\hline \multirow{2}{*}{ Colour parameters } & Storage & \multicolumn{4}{c}{ Treatments } \\
\cline { 2 - 6 } & (days) & $\mathrm{T}_{0}$ & $\mathrm{~T}_{1}$ & $\mathrm{~T}_{2}$ & $\mathrm{~T}_{3}$ \\
\hline & 0 & $25.86 \pm 0.27^{\mathrm{Ad}}$ & $27.03 \pm 0.30^{\mathrm{Ac}}$ & $28.16 \pm 0.23^{\mathrm{Ab}}$ & $29.13 \pm 0.43^{\mathrm{Aa}}$ \\
$\mathrm{L}^{*}$ & 20 & $25.03 \pm 0.43^{\mathrm{Bd}}$ & $26.33 \pm 0.14^{\mathrm{Bc}}$ & $27.62 \pm 0.34^{\mathrm{Bb}}$ & $28.76 \pm 0.38^{\mathrm{ABa}}$ \\
& 40 & $24.56 \pm 0.52^{\mathrm{BCd}}$ & $25.90 \pm 0.08^{\mathrm{Cc}}$ & $27.13 \pm 0.27^{\mathrm{Cb}}$ & $28.33 \pm 0.22^{\mathrm{BCa}}$ \\
& 60 & $23.86 \pm 0.15^{\mathrm{CDd}}$ & $25.36 \pm 0.21^{\mathrm{Dc}}$ & $26.61 \pm 0.16^{\mathrm{Db}}$ & $27.96 \pm 0.15^{\mathrm{Ca}}$ \\
& 80 & $23.50 \pm 0.59^{\mathrm{Dd}}$ & $25.11 \pm 0.19^{\mathrm{Dc}}$ & $26.50 \pm 0.09^{\mathrm{Db}}$ & $27.88 \pm 0.08^{\mathrm{Ca}}$ \\
\hline & 0 & $35.26 \pm 0.62^{\mathrm{Aa}}$ & $35.03 \pm 0.13^{\mathrm{Aa}}$ & $34.83 \pm 0.16^{\mathrm{Aa}}$ & $34.13 \pm 0.06^{\mathrm{Ab}}$ \\
& 20 & $35.13 \pm 0.48^{\mathrm{ABa}}$ & $34.82 \pm 0.32^{\mathrm{Aab}}$ & $34.53 \pm 0.07^{\mathrm{ABbc}}$ & $34.06 \pm 0.19^{\mathrm{Ac}}$ \\
$\mathrm{a}^{*}$ & 40 & $34.86 \pm 0.53^{\mathrm{ABa}}$ & $34.46 \pm 0.51^{\mathrm{BCab}}$ & $34.13 \pm 0.29^{\mathrm{BCab}}$ & $33.83 \pm 0.57^{\mathrm{Ab}}$ \\
& 60 & $34.26 \pm 0.21^{\mathrm{BCa}}$ & $34.03 \pm 0.24^{\mathrm{CDa}}$ & $33.93 \pm 0.57^{\mathrm{Ca}}$ & $33.53 \pm 0.57^{\mathrm{ABa}}$ \\
& 0 & $33.91 \pm 0.44^{\mathrm{Ca}}$ & $33.66 \pm 0.08^{\mathrm{Da}}$ & $33.57 \pm 0.11^{\mathrm{Ca}}$ & $33.06 \pm 0.15^{\mathrm{Bb}}$ \\
\hline \multirow{4}{*}{$\mathrm{b}^{*}$} & $14.91 \pm 0.25^{\mathrm{Db}}$ & $16.65 \pm 0.17^{\mathrm{Ba}}$ & $16.76 \pm 0.32^{\mathrm{Aa}}$ & $17.06 \pm 0.13^{\mathrm{Aa}}$ \\
& 40 & $15.13 \pm 0.09^{\mathrm{Db}}$ & $16.94 \pm 0.31^{\mathrm{ABa}}$ & $16.86 \pm 0.06^{\mathrm{Aa}}$ & $17.13 \pm 0.08^{\mathrm{Aa}}$ \\
& 60 & $15.63 \pm 0.16^{\mathrm{Cb}}$ & $17.13 \pm 0.52^{\mathrm{ABa}}$ & $16.94 \pm 0.24^{\mathrm{Aa}}$ & $17.26 \pm 0.56^{\mathrm{Aa}}$ \\
& 80 & $17.26 \pm 0.03^{\mathrm{Aa}}$ & $17.26 \pm 0.07^{\mathrm{Aa}}$ & $17.16 \pm 0.19^{\mathrm{Aa}}$ & $17.32 \pm 0.32^{\mathrm{Aa}}$ \\
& 0 & $2.36 \pm 0.01^{\mathrm{Aa}}$ & $2.01 \pm 0.01^{\mathrm{Bc}}$ & $2.07 \pm 0.02^{\mathrm{Ab}}$ & $1.96 \pm 0.02^{\mathrm{Ad}}$ \\
$\mathrm{a}^{*} / \mathrm{b}^{*}$ & 20 & $2.32 \pm 0.03^{\mathrm{Ba}}$ & $2.05 \pm 0.01^{\mathrm{Ab}}$ & $2.05 \pm 0.01^{\mathrm{Ab}}$ & $1.97 \pm 0.02^{\mathrm{Ac}}$ \\
& 40 & $2.23 \pm 0.01^{\mathrm{Ca}}$ & $2.01 \pm 0.02^{\mathrm{Bb}}$ & $2.01 \pm 0.01^{\mathrm{Bb}}$ & $1.95 \pm 0.01^{\mathrm{Ac}}$ \\
& 60 & $2.07 \pm 0.02^{\mathrm{Da}}$ & $1.97 \pm 0.01^{\mathrm{Cb}}$ & $1.98 \pm 0.03^{\mathrm{BCb}}$ & $1.96 \pm 0.02^{\mathrm{Ab}}$ \\
& $1.96 \pm 0.02^{\mathrm{Ea}}$ & $1.94 \pm 0.03^{\mathrm{Ca}}$ & $1.95 \pm 0.02^{\mathrm{Ca}}$ & $1.94 \pm 0.01^{\mathrm{Aa}}$ \\
\hline
\end{tabular}

Values are presented as mean \pm standard deviation, $n=3$. Values with different lowercase superscript within the same row are significantly different $(\mathrm{P}<0.05)$. Values with different uppercase superscript within the same column are significantly different $(\mathrm{P}<0.05)$.

during storage may be related to the oxidation of phenolic compounds available naturally in tomatoes (Yildiz and Baysal, 2007). Additionally, the discolouration of tomato paste samples could be attributed to the oxidation of lycopene and eventual discolouration of the paste samples during storage (Basak, 2018). The results obtained for the effects of storage time on the colour parameters of tomato pastes in the current work were consistent with those reported earlier (Liu et al., 2010; Maity and Raju, 2015; Basak, 2018).

\subsection{Ascorbic acid content}

The changes in ascorbic acid content (AAC) during the storage period of tomato paste samples are shown in Table 3. It could be noticed that the AAC of all samples decreased significantly $(\mathrm{P}<0.05)$ from $64.13-64.83$ to $43.73-45.56 \mathrm{mg} / 100 \mathrm{~g}$ after 0 and 80 days of storage, respectively. The decrease in AAC of tomato pastes may be due to the oxidation of ascorbic acid during storage (Apaiah and Barringer, 2001). Among all treatments, the control showed the highest AAC, whereas the tomato paste with $6 \%$ RF showed the lowest. Since RF contains lower content of ascorbic acid, this may have been responsible for the differences in $\mathrm{AAC}$ between tomato paste samples. Our results were consistent with those reported by other researchers (Koh et al., 2012) who observed that the AAC of tomato paste decreased during storage at ambient conditions. The degradation of ascorbic acid could be clearly noticed in processed tomato products during the storage at temperatures of $30^{\circ} \mathrm{C}$ or greater (Lavelli and Giovanelli, 2003). The degradation rate of ascorbic acid in tomato products increased with the increase in storage temperature, storage period, and moisture content of the product (Goula and Adamopoulos, 2006). However, the effects of storage time on AAC of different tomato paste samples in the current study were similar, as they revealed the same trend.

\subsection{Total titratable acidity (TTA) and $p H$}

The changes in TTA of tomato pastes enriched with different ratios of RF during storage are shown in Table 4. Results showed that TTA values ranged from 1.48 to 1.75 and 1.56 to $1.93 \%$ at day 0 and 80 of storage, respectively. The TTA of tomato paste samples were approximately stable for the first 20 days and increased significantly $(\mathrm{P}<0.05)$ in all samples until 60 days of storage. After 80 days of storage, the TTA of control and paste with $2 \%$ RF increased slightly while samples 
Table 3. Changes of ascorbic acid content $(\mathrm{mg} / 100 \mathrm{~g})$ in tomato pastes during storage.

\begin{tabular}{ccccc}
\hline \multirow{2}{*}{$\begin{array}{c}\text { Storage } \\
\text { days }\end{array}$} & $\mathrm{T}_{0}$ & $\mathrm{~T}_{1}$ & $\mathrm{~T}_{2}$ & $\mathrm{~T}_{3}$ \\
\cline { 2 - 5 } & $64.83 \pm 0.92^{\mathrm{Aa}}$ & $64.61 \pm 0.84^{\mathrm{Aa}}$ & $64.33 \pm 0.58^{\mathrm{Aa}}$ & $64.13 \pm 0.77^{\mathrm{Aa}}$ \\
0 & $59.12 \pm 0.87^{\mathrm{Ba}}$ & $58.86 \pm 0.91^{\mathrm{Ba}}$ & $58.53 \pm 0.84^{\mathrm{Ba}}$ & $58.43 \pm 1.02^{\mathrm{Ba}}$ \\
40 & $52.13 \pm 0.94^{\mathrm{Ca}}$ & $51.63 \pm 0.66^{\mathrm{Ca}}$ & $51.36 \pm 1.07^{\mathrm{Ca}}$ & $51.08 \pm 0.83^{\mathrm{Ca}}$ \\
60 & $47.86 \pm 0.57^{\mathrm{Da}}$ & $47.23 \pm 0.55^{\mathrm{Da}}$ & $47.14 \pm 0.73^{\mathrm{Da}}$ & $46.96 \pm 1.07^{\mathrm{Da}}$ \\
80 & $45.56 \pm 0.85^{\mathrm{Ea}}$ & $44.16 \pm 0.77^{\mathrm{Eb}}$ & $43.91 \pm 0.65^{\mathrm{Eb}}$ & $43.73 \pm 0.57^{\mathrm{Eb}}$ \\
\hline
\end{tabular}

Values are presented as mean \pm standard deviation, $n=3$. Values with different lowercase superscript within the same row are significantly different $(\mathrm{P}<0.05)$. Values with different uppercase superscript within the same column are significantly different $(\mathrm{P}<0.05)$.

Table 4. Changes of acidity (\% citric acid) and $\mathrm{pH}$ in tomato pastes during storage.

\begin{tabular}{cccccc}
\hline \multirow{2}{*}{ Parameter } & $\begin{array}{c}\text { Storage } \\
\text { days }\end{array}$ & $\mathrm{T}_{0}$ & $\mathrm{~T}_{1}$ & $\mathrm{~T}_{2}$ & $\mathrm{~T}_{3}$ \\
\cline { 2 - 5 } & 0 & $1.75 \pm 0.03^{\mathrm{Da}}$ & $1.63 \pm 0.05^{\mathrm{Cb}}$ & $1.54 \pm 0.01^{\mathrm{Bc}}$ & $1.48 \pm 0.05^{\mathrm{Bc}}$ \\
& 20 & $1.77 \pm 0.05^{\mathrm{CDa}}$ & $1.65 \pm 0.03^{\mathrm{Cb}}$ & $1.55 \pm 0.02^{\mathrm{Bc}}$ & $1.48 \pm 0.03^{\mathrm{Bd}}$ \\
Acidity & 40 & $1.84 \pm 0.05^{\mathrm{BCa}}$ & $1.69 \pm 0.03^{\mathrm{BCb}}$ & $1.67 \pm 0.03^{\mathrm{Ab}}$ & $1.52 \pm 0.04^{\mathrm{ABc}}$ \\
$(\%)$ & 60 & $1.89 \pm 0.03^{\mathrm{ABa}}$ & $1.75 \pm 0.04^{\mathrm{ABb}}$ & $1.71 \pm 0.01^{\mathrm{Ab}}$ & $1.55 \pm 0.03^{\mathrm{ABc}}$ \\
& 80 & $1.93 \pm 0.05^{\mathrm{Aa}}$ & $1.81 \pm 0.03^{\mathrm{Ab}}$ & $1.72 \pm 0.05^{\mathrm{Ac}}$ & $1.56 \pm 0.04^{\mathrm{Ad}}$ \\
\hline \multirow{2}{*}{$\mathrm{pH}$} & 0 & $4.38 \pm 0.05^{\mathrm{Aa}}$ & $4.41 \pm 0.04^{\mathrm{Aa}}$ & $4.43 \pm 0.04^{\mathrm{Aa}}$ & $4.46 \pm 0.05^{\mathrm{Aa}}$ \\
& 20 & $4.31 \pm 0.07^{\mathrm{Aa}}$ & $4.33 \pm 0.05^{\mathrm{Ba}}$ & $4.36 \pm 0.04^{\mathrm{Aa}}$ & $4.38 \pm 0.03^{\mathrm{Aa}}$ \\
& 40 & $3.86 \pm 0.04^{\mathrm{Bc}}$ & $4.01 \pm 0.03^{\mathrm{Cb}}$ & $4.05 \pm 0.04^{\mathrm{Bab}}$ & $4.11 \pm 0.06^{\mathrm{Ba}}$ \\
& 60 & $3.65 \pm 0.05^{\mathrm{Cc}}$ & $3.86 \pm 0.04^{\mathrm{Db}}$ & $3.90 \pm 0.04^{\mathrm{Cab}}$ & $3.97 \pm 0.07^{\mathrm{Ca}}$ \\
& 80 & $3.52 \pm 0.09^{\mathrm{Db}}$ & $3.81 \pm 0.05^{\mathrm{Da}}$ & $3.86 \pm 0.07^{\mathrm{Ca}}$ & $3.94 \pm 0.05^{\mathrm{Ca}}$ \\
\hline
\end{tabular}

Values are presented as mean \pm standard deviation, $n=3$. Values with different lowercase superscript within the same row are significantly different $(\mathrm{P}<0.05)$. Values with different uppercase superscript within the same column are significantly different $(\mathrm{P}<0.05)$.

containing $4 \%$ and $6 \%$ RF exhibited no increase in TTA. It could be noticed that the increase in TTA was more obvious in the control sample and the paste with $2 \% \mathrm{RF}$ through storage at ambient temperature. The trends obtained for the effects of storage time on the TTA of tomato paste samples in this study were similar to those reported earlier (Olaniran et al., 2015; Alqahtani, 2020). However, the values of TTA after 80 days of storage at ambient temperature were in-line with the values highlighted in the international food standards provided by the world food programme i.e. TTA must not exceed 7\% (WFP, 2011).

The $\mathrm{pH}$ values of tomato paste samples ranged from 4.38 to 4.46 and 3.52 to $3.94 \%$ at day 0 and 80 of storage, respectively (Table 4). A slight decrease in the $\mathrm{pH}$ values of tomato paste samples was observed after 20 days of storage. After 40 days of storage, a dramatic decrease in the $\mathrm{pH}$ values of tomato paste samples was observed. All samples revealed a slight decrease in $\mathrm{pH}$ values after 60 and 80 days of storage. However, samples containing RF showed less decrease in $\mathrm{pH}$ values as compared to control. In general, after 80 days of storage at ambient temperature, the $\mathrm{pH}$ values of all samples were consistent with the recommendations of the Codex Alimentarius, i.e. $\mathrm{pH}$ must not exceed 4.5
(FAO, 2017). The results obtained for the effects of storage time on the $\mathrm{pH}$ values of tomato paste in the current study were in agreement with those reported earlier (Olaniran et al., 2015; Alqahtani, 2020; Gallo et al., 2020). The increase in TTA and the decrease in $\mathrm{pH}$ of tomato paste samples could be due to the organic acids produced by lactic acid bacteria. Moreover, the oxidation of alcohol and aldehyde during processing may have been responsible for the increase of acidity (Olaniran et al., 2015). However, the increase in acidity has an inhibitory impact on the growth rate of pathogens. The higher content of the RF was associated with a lower level of acidification. For this reason, it can be concluded that RF may act as a $\mathrm{pH}$ stabilizer.

\subsection{Total soluble solids (TSS) and Bostwick consistency}

The effects of the storage period on the TSS of tomato paste samples with different levels of RF addition are displayed in Table 5. The TSS of tomato pastes ranged from 35.04 to 37.83 and 37.03 to $38.73 \%$ at day 0 and 80 of storage, respectively. For the first 20 days of storage, the TSS values of tomato pastes with 2, 4 and $6 \%$ RF were approximately stable, while the control sample showed increased values. A slight increase in TSS of control and tomato pastes contained RF was 
Table 5. Changes of total soluble solids (TSS) and Bostwick in tomato pastes during storage.

\begin{tabular}{cccccc}
\hline \multirow{2}{*}{ Parameter } & $\begin{array}{c}\text { Storage } \\
\text { days }\end{array}$ & $\mathrm{T}_{0}$ & $\mathrm{~T}_{1}$ & $\mathrm{~T}_{2}$ & $\mathrm{~T}_{3}$ \\
\cline { 2 - 6 } & 0 & $35.04 \pm 0.72^{\mathrm{Cb}}$ & $35.81 \pm 0.85^{\mathrm{Cb}}$ & $36.47 \pm 0.57^{\mathrm{Bab}}$ & $37.83 \pm 0.94^{\mathrm{Aa}}$ \\
& 20 & $35.53 \pm 0.54^{\mathrm{BCb}}$ & $35.98 \pm 0.48^{\mathrm{Cb}}$ & $36.58 \pm 0.68^{\mathrm{Bb}}$ & $37.91 \pm 0.65^{\mathrm{Aa}}$ \\
TSS & 40 & $36.11 \pm 0.46^{\mathrm{ABCb}}$ & $36.45 \pm 0.53^{\mathrm{BCb}}$ & $36.92 \pm 0.68^{\mathrm{Bb}}$ & $38.23 \pm 0.77^{\mathrm{Aa}}$ \\
$\left({ }^{\circ}\right.$ Brix $)$ & 60 & $36.73 \pm 0.67^{\mathrm{ABb}}$ & $37.53 \pm 0.53^{\mathrm{ABab}}$ & $38.03 \pm 0.55^{\mathrm{Aa}}$ & $38.36 \pm 0.72^{\mathrm{Aa}}$ \\
& 80 & $37.03 \pm 0.74^{\mathrm{Ab}}$ & $38.03 \pm 0.68^{\mathrm{Aab}}$ & $38.53 \pm 0.49^{\mathrm{Aa}}$ & $38.73 \pm 0.61^{\mathrm{Aa}}$ \\
\hline Bostwick & 0 & $10.81 \pm 0.24^{\mathrm{Da}}$ & $9.84 \pm 0.32^{\mathrm{Db}}$ & $8.53 \pm 0.29^{\mathrm{Ec}}$ & $7.33 \pm 0.37^{\mathrm{Dd}}$ \\
$(\mathrm{cm})$ & 40 & $12.10 \pm 0.23^{\mathrm{Ba}}$ & $11.23 \pm 0.37^{\mathrm{Bb}}$ & $9.63 \pm 0.15^{\mathrm{Cc}}$ & $8.94 \pm 0.19^{\mathrm{Bd}}$ \\
& 60 & $12.43 \pm 0.14^{\mathrm{Ba}}$ & $11.52 \pm 0.22^{\mathrm{ABb}}$ & $10.53 \pm 0.18^{\mathrm{Bc}}$ & $9.33 \pm 0.12^{\mathrm{ABd}}$ \\
& 80 & $12.90 \pm 0.22^{\mathrm{Aa}}$ & $11.86 \pm 0.17^{\mathrm{Ab}}$ & $11.07 \pm 0.24^{\mathrm{Ac}}$ & $9.73 \pm 0.21^{\mathrm{Ad}}$ \\
\hline
\end{tabular}

Values are presented as mean \pm standard deviation, $n=3$. Values with different lowercase superscript within the same row are significantly different $(\mathrm{P}<0.05)$. Values with different uppercase superscript within the same column are significantly different $(\mathrm{P}<0.05)$.

observed after 40 days of storage. The same trend for TSS changes was observed after 60 days of storage. After 80 days of storage, the TSS of control and tomato paste with $2 \% \mathrm{RF}$ increased slightly, while samples containing 4 and $6 \%$ RF exhibited an insignificant $(\mathrm{P}>$ 0.05 ) increase in TSS. Our results were similar to those reported previously (Villari et al., 1994; Alqahtani, 2020). Generally, the TSS of tomato pastes revealed a slight increase throughout the storage period particularly for control and pastes with a lower amount of RF, while samples with higher content of RF were more stable during storage regarding TSS changes. It could be expected that the increase in TSS might be due to the hydrolysis of polysaccharides during storage. Moreover, the increase in TSS during storage could be related to the conversion of starch to sugars (Gujral et al., 2002). On contrary, Liu et al. (2010) observed fluctuations in TSS values of tomato powders, but there were no significant changes during storage for 5 months at 0,25 and $37^{\circ} \mathrm{C}$. However, Basak (2018) reported that no significant variations in TSS of tomato pastes were observed during storage.

The Bostwick consistency values of tomato paste samples ranged from 7.33 to 10.81 and 9.73 to 12.90 at day 0 and 80 of storage, respectively (Table 5). Significant $(\mathrm{P}<0.05)$ differences were observed in the Bostwick consistency values of tomato pastes at day 0 of storage. Tomato paste with $6 \% \mathrm{RF}$ showed the lowest Bostwick consistency value (was the thickest), whereas control sample showed the highest (was the thinnest). The Bostwick consistency values of tomato pastes decreased with the increase of RF addition, which could be related to the physico-chemical properties of starch which is considered as a thickening agent (Juszczak et al., 2013). A slight increase in the Bostwick consistency values of tomato paste samples was observed after 20 days of storage. The same trends were observed after 40 ,
60 and 80 days of storage, taking into account that the tomato pastes with 4 and $6 \%$ RF showed the least increasing ratio. Generally, tomato paste trails tended to become less viscous through the storage period, which could be related to the hydrolysis of polymers, particularly under acidic conditions. Moreover, at $\mathrm{pH}$ lower than 4, the free acids are produced, which may have been responsible for the precipitation of the polymers (Gujral et al., 2002). The addition of RF resulted in keeping the viscosity, which could be related to the binding of water by the starch molecules leading to an increase in the resistance to flow. The results obtained for the effects of storage time on the Bostwick consistency of tomato paste samples in the current study were consistent with the findings reported previously (Anthon and Barrett, 2010; Jafari et al., 2017).

\subsection{Sensory evaluation}

The changes in sensory scores during the storage period of tomato paste samples are presented in Table 6 . It could be noticed that the colour scores of freshly processed tomato pastes decreased insignificantly $(\mathrm{P}>$ 0.05 ) with the increase of RF addition, which could be due to the dilution effect of RF on the final colour of the product. The colour scores of tomato pastes decreased slightly after the first 20 days of storage. The same trend was observed in all samples until 60 days of storage. After 80 days of storage, the colour score of control and paste with $2 \% \mathrm{RF}$ decreased slightly, whereas tomato pastes contained 4 and 6\% RF were approximately stable. However, all samples were acceptable after 80 days of storage. Sensory results showed insignificant (P $>0.05$ ) changes in flavour scores of freshly processed tomato pastes. Likewise, during storage, the flavour scores of tomato pastes decreased slightly after the first 20 days of storage. The same trend was observed for all samples until 80 days of storage. Generally, insignificant 
Table 6. Changes of sensory scores in tomato pastes during storage.

\begin{tabular}{|c|c|c|c|c|c|}
\hline \multirow{2}{*}{$\begin{array}{c}\text { Quality } \\
\text { attributes }\end{array}$} & \multirow{2}{*}{$\begin{array}{c}\text { Storage } \\
\text { days }\end{array}$} & \multicolumn{4}{|c|}{ Treatments } \\
\hline & & $\mathrm{T}_{0}$ & $\mathrm{~T}_{1}$ & $\mathrm{~T}_{2}$ & $\mathrm{~T}_{3}$ \\
\hline \multirow{5}{*}{ Colour } & 0 & $8.66 \pm 0.08^{\mathrm{Aa}}$ & $8.15 \pm 0.20^{\mathrm{Ab}}$ & $7.91 \pm 0.35^{\mathrm{Ab}}$ & $7.82 \pm 0.21^{\mathrm{Ab}}$ \\
\hline & 20 & $8.38 \pm 0.21^{\mathrm{ABa}}$ & $7.92 \pm 0.09^{\mathrm{ABb}}$ & $7.74 \pm 0.08^{\mathrm{ABb}}$ & $7.64 \pm 0.17^{\mathrm{ABb}}$ \\
\hline & 40 & $8.08 \pm 0.17^{\mathrm{BCa}}$ & $7.74 \pm 0.32^{\mathrm{ABCa}}$ & $7.58 \pm 0.23^{\mathrm{ABa}}$ & $7.51 \pm 0.38^{\mathrm{ABa}}$ \\
\hline & 60 & $7.82 \pm 0.33^{\mathrm{CDa}}$ & $7.63 \pm 0.19^{\mathrm{BCa}}$ & $7.46 \pm 0.19^{\mathrm{Ba}}$ & $7.42 \pm 0.07^{\mathrm{ABa}}$ \\
\hline & 80 & $7.45 \pm 0.28^{\mathrm{Da}}$ & $7.41 \pm 0.36^{\mathrm{Ca}}$ & $7.39 \pm 0.16^{\mathrm{Ba}}$ & $7.33 \pm 0.24^{\mathrm{Ba}}$ \\
\hline \multirow{5}{*}{ Flavour } & 0 & $8.41 \pm 0.22^{\mathrm{Aa}}$ & $8.22 \pm 0.04^{\mathrm{Aa}}$ & $8.13 \pm 0.14^{\mathrm{Aa}}$ & $8.06 \pm 0.32^{\mathrm{Aa}}$ \\
\hline & 20 & $8.32 \pm 0.08^{\mathrm{ABa}}$ & $8.15 \pm 0.21^{\mathrm{Aa}}$ & $8.04 \pm 0.22^{\mathrm{ABa}}$ & $8.00 \pm 0.07^{\mathrm{Aa}}$ \\
\hline & 40 & $7.91 \pm 0.31^{\mathrm{BCa}}$ & $7.90 \pm 0.07^{\mathrm{ABa}}$ & $7.85 \pm 0.06^{\mathrm{BCa}}$ & $7.74 \pm 0.09^{\mathrm{ABa}}$ \\
\hline & 60 & $7.74 \pm 0.19^{\mathrm{Ca}}$ & $7.76 \pm 0.17^{\mathrm{BCa}}$ & $7.68 \pm 0.13^{\mathrm{CDa}}$ & $7.55 \pm 0.24^{\mathrm{Ba}}$ \\
\hline & 80 & $7.52 \pm 0.27^{\mathrm{Ca}}$ & $7.53 \pm 0.25^{\mathrm{Ca}}$ & $7.50 \pm 0.09^{\mathrm{Da}}$ & $7.46 \pm 0.18^{\mathrm{Ba}}$ \\
\hline \multirow{5}{*}{ Texture } & 0 & $8.00 \pm 0.32^{\mathrm{Ac}}$ & $8.42 \pm 0.21^{\mathrm{Abc}}$ & $8.93 \pm 0.30^{\mathrm{Aa}}$ & $8.58 \pm 0.18^{\mathrm{Aab}}$ \\
\hline & 20 & $7.91 \pm 0.29^{\mathrm{ABb}}$ & $8.08 \pm 0.13^{\mathrm{Bb}}$ & $8.85 \pm 0.12^{\mathrm{Aa}}$ & $8.50 \pm 0.24^{\mathrm{Aa}}$ \\
\hline & 40 & $7.53 \pm 0.04^{\mathrm{Bc}}$ & $8.00 \pm 0.29^{\mathrm{Bb}}$ & $8.41 \pm 0.20^{\mathrm{Ba}}$ & $8.37 \pm 0.05^{\mathrm{Aa}}$ \\
\hline & 60 & $7.04 \pm 0.17^{\mathrm{Cb}}$ & $7.83 \pm 0.08^{\mathrm{Ba}}$ & $7.91 \pm 0.26^{\mathrm{Ca}}$ & $7.80 \pm 0.27^{\mathrm{Ba}}$ \\
\hline & 80 & $6.51 \pm 0.05^{\mathrm{Db}}$ & $7.75 \pm 0.13^{\mathrm{Ba}}$ & $7.83 \pm 0.09^{\mathrm{Ca}}$ & $7.76 \pm 0.14^{\mathrm{Ba}}$ \\
\hline \multirow{5}{*}{$\begin{array}{c}\text { Overall } \\
\text { acceptability }\end{array}$} & 0 & $8.31 \pm 0.18^{\mathrm{Aa}}$ & $8.27 \pm 0.33^{\mathrm{Aa}}$ & $8.52 \pm 0.17^{\mathrm{Aa}}$ & $8.13 \pm 0.22^{\mathrm{Aa}}$ \\
\hline & 20 & $8.03 \pm 0.25^{\mathrm{ABa}}$ & $8.05 \pm 0.09^{\mathrm{ABa}}$ & $8.23 \pm 0.19^{\mathrm{ABa}}$ & $8.00 \pm 0.06^{\mathrm{ABa}}$ \\
\hline & 40 & $7.75 \pm 0.11^{\mathrm{BCa}}$ & $7.82 \pm 0.26^{\mathrm{BCa}}$ & $8.00 \pm 0.31^{\mathrm{BCa}}$ & $7.85 \pm 0.13^{\mathrm{ABCa}}$ \\
\hline & 60 & $7.44 \pm 0.05^{\mathrm{Ca}}$ & $7.68 \pm 0.17^{\mathrm{BCa}}$ & $7.75 \pm 0.07^{\mathrm{CDa}}$ & $7.71 \pm 0.32^{\mathrm{BCa}}$ \\
\hline & 80 & $7.00 \pm 0.23^{\mathrm{Db}}$ & $7.44 \pm 0.18^{\mathrm{Ca}}$ & $7.53 \pm 0.25^{\mathrm{Da}}$ & $7.48 \pm 0.14^{\mathrm{Ca}}$ \\
\hline
\end{tabular}

Values are presented as mean \pm standard deviation, $n=3$. Values with different lowercase superscript within the same row are significantly different $(\mathrm{P}<0.05)$. Values with different uppercase superscript within the same column are significantly different $(\mathrm{P}<0.05)$.

$(\mathrm{P}>0.05)$ variations in the flavour of tomato pastes were observed during storage. Regarding texture, pastes containing RF were smoother as compared to control. The scores for the mouthfeel of tomato pastes containing 2,4 , and $6 \%$ RF were significantly higher as compared to the control sample. Our findings for texture scores were similar to those reported by Sit et al. (2014) who observed that the addition of taro starch showed a significant increase in the texture properties of tomato ketchup. Generally, among all tested samples, the tomato paste containing 4\% RF showed the highest overall acceptability scores with 8.52 and 7.53 during 0 and 80 days after storage, respectively. The results of sensory scores reported in the current investigation were consistent with those reported by other authors (Sit et al., 2014; Basak, 2018).

\section{Conclusion}

Tomato paste incorporated with RF showed higher $\mathrm{L}^{*}$ and $\mathrm{b}^{*}$ values and lower $\mathrm{a}^{*}$ values than control. The protein, carbohydrate and fat content of tomato pastes contained RF increased, whereas ash and fibre content decreased slightly. Texture analyses, colour measurements, and sensory evaluation showed that the addition of RF improved texture properties of the pastes directly after processing and during the storage period without affecting the colour, flavour, and overall acceptability. The $a^{*} / b^{*}$ ratio values of the pastes contained RF were approximately stable during storage and were at acceptable levels. The $\mathrm{pH}$ and ascorbic acid content of tomato paste samples decreased slightly, whereas acidity, TSS, and Bostwick increased during storage. Tomato paste containing 4\% RF showed the highest sensory scores among all tested samples at zero time and during the storage period. Such findings indicate that RF may be used as a novel and inexpensive thickening agent in food processing. Further studies are required for applications in food industries and optimization of processing conditions.

\section{Conflict of interest}

The authors have declared no conflicts of interest.

\section{References}

Abano, E.E., Ma, H. and Qu, W. (2012). Influence of combined microwave-vacuum drying on drying kinetics and quality of dried tomato slices. Journal of Food Quality, 35(3), 159-168. https:// doi.org/10.1111/j.1745-4557.2012.00446.x 
Ali, S., Singh, B. and Sharma, S. (2020). Effect of processing temperature on morphology, crystallinity, functional properties, and in vitro digestibility of extruded corn and potato starches. Journal of Food Processing and Preservation, 44(7), e14531. https:// doi.org/10.1111/jfpp.14531

Alqahtani, N.K. (2020). Physico-chemical and sensorial properties of ketchup enriched with Khalas date pits powder. The Scientific Journal of King Faisal University, 21(2), 172-176. https://doi.org/10.37575/ $\mathrm{b} / \mathrm{agr} / 2030$

Anthon, G.E. and Barrett, D.M. (2010). Changes in tomato paste during storage and the effects of heating on consistency of reconstituted tomato paste. Journal of Texture Studies, 41(3), 262-278. https:// doi.org/10.1111/j.1745-4603.2010.00225.x

AOAC. (2006). Official methods of analysis, 18th ed. Washington, DC, USA: Association of Official Analytical Chemists,

Apaiah, R.K. and Barringer, S.A. (2001). Quality loss during tomato paste production versus sauce storage. Journal of Food Processing and Preservation, 25(4), 237-250. https://doi.org/10.1111/j.17454549.2001.tb00458.x

Banat, F., Jumah, R., Al-Asheh, S. and Hammad, S. (2002). Effect of operating parameters on the spray drying of tomato paste. Engineering in Life Sciences, 2(12), 403-407. https://doi.org/10.1002/1618-2863 (20021210)2:12<403::AID-ELSC403>3.0.CO;2-G

Basak, S. (2018). Shelf life extension of tomato paste through organoleptically acceptable concentration of betel leaf essential oil under accelerated storage environment. Journal of Food Science, 83(5), 13961403. https://doi.org/10.1111/1750-3841.14133

Donkor, S., Agyekum, A.A., Akuamoa, F., Adu-Bobi, N.A.K., Achel, D.G., Asare, I.K. and Kyei, J. (2015). Antioxidant potentials of tomato paste extracts found on major markets in Accra Metropolis. American Journal of Applied Chemistry, 3(5), 158-163. https:// doi.org/10.11648/j.ajac.20150305.11

Eke-Ejiofor, J. (2015). Comparative evaluation of lycopene content and some chemical properties of commonly consumed brands of tomato paste in Portharcourt, South-south, Nigeria. Journal of Food and Nutrition Sciences, 3(2), 35-37. https:// doi.org/10.11648/j.jfns.20150302.12

FAO. (2017). Food and Agriculture Organization of the United Nations. Codex alimentarius, standard for preserved tomatoes. Retrieved on August 21, 2020 from: http://www.fao.org/fao-whocodexalimentarius/codex-texts/list-standards/en/

FAO. (2018). Food and Agriculture Organization of the
United Nations. FAOSTAT. Retrieved on August 30, 2020 from: http://www.fao.org/faostat/en/\#data/QC

Farahnaky, A., Majdinasab, M., Majzoobi, M. and Mesbahi, G. (2010). A comparative study of physicochemical and rheological properties of Iranian tomato pastes. International Journal of Food Engineering, 6(1), 1-14. https:// doi.org/10.2202/1556-3758.1571

Gallo, M., Passannanti, F., D'Apolito, E., Nigro, F., Salameh, D. and Nigro, R. (2020). Biotechnological production of natural sweeteners and preservatives on tomato paste. Journal of Food Process Engineering, 43(2), e13327. https://doi.org/10.1111/ jfpe. 13327

Ganje, M., Jafari, S.M., Dusti, A., Dehnad, D., Amanjani, M. and Ghanbari, V. (2016). Modeling quality changes in tomato paste containing microencapsulated olive leaf extract by accelerated shelf life testing. Food and Bioproducts Processing, 97, 12-19. https://doi.org/10.1016/j.fbp.2015.10.002

Giovanelli, G. and Paradiso, A. (2002). Stability of dried and intermediate moisture tomato pulp during storage. Journal of Agricultural and Food Chemistry, 50(25), 7277-7281. https:// doi.org/10.1021/jf025595r

Goula, A.M. and Adamopoulos, K.G. (2006). Retention of ascorbic acid during drying of tomato halves and tomato pulp. Drying Technology, 24(1), 57-64. https://doi.org/10.1080/07373930500538709

Gujral, H.S., Sharma, A. and Singh, N. (2002). Effect of hydrocolloids, storage temperature, and duration on the consistency of tomato ketchup. International Journal of Food Properties, 5(1), 179-191. https:// doi.org/10.1081/JFP-120015600

Jafari, S.M., Amanjani, M., Ganjeh, M., Katouzian, I. and Sharifi., N. (2018). The influence of storage time and temperature on the corrosion and pressure changes within tomato paste cans with different filling rates. Journal of Food Engineering, 228, 3237. https://doi.org/10.1016/j.jfoodeng.2018.02.008

Jafari, S.M., Ganje, M., Dehnad, D., Ghanbari, V. and Hajitabar, J. (2017). Arrhenius equation modeling for the shelf life prediction of tomato paste containing a natural preservative. Journal of the Science of Food and Agriculture, 97(15), 52165222. https://doi.org/10.1002/jsfa.8404

Juszczak, L., Oczadły, Z. and Gałkowska, D. (2013). Effect of modified starches on rheological properties of ketchup. Food and Bioprocess Technology, 6, 1251-1260. https://doi.org/10.1007/s11947-0120813-x

Kaushal, P., Kumar, V. and Sharma, H.K. (2012). 
Comparative study of physicochemical, functional, antinutritional and pasting properties of taro (Colocasia esculenta), rice (Oryza sativa) flour, pigeonpea (Cajanus cajan) flour and their blends. LWT - Food Science and Technology, 48(1), 59-68. https://doi.org/10.1016/j.lwt.2012.02.028

Kelebek, H., Selli, S., Kadiroglu, P., Kola, O., Kesen, S., Uçar, B. and Çetiner, B. (2017). Bioactive compounds and antioxidant potential in tomato pastes as affected by hot and cold break process. Food Chemistry, 220, 31-41. https:// doi.org/10.1016/j.foodchem.2016.09.190

Koh, E., Charoenprasert, S. and Mitchell, A.E. (2012). Effects of industrial tomato paste processing on ascorbic acid, flavonoids and carotenoids and their stability over one-year storage. Journal of the Science of Food and Agriculture, 92(1), 23-28. https://doi.org/10.1002/jsfa.4580

Lavelli, V. and Giovanelli, G. (2003). Evaluation of heat and oxidative damage during storage of processed tomato products. II. Study of oxidative damage indices. Journal of the Science of Food and Agriculture, 83(9), 966-971. https://doi.org/10.1002/ jsfa. 1433

Liu, F., Cao, X., Wang, H. and Liao, X. (2010). Changes of tomato powder qualities during storage. Powder Technology, 204(1), 159-166. https:// doi.org/10.1016/j.powtec.2010.08.002

Lopez, A.C.B., Pereira, A.J.G. and Junqueira, R.G. (2004). Flour mixture of rice flour, corn and cassava starch in the production of gluten-free white bread. Brazilian Archives of Biology and Technology, 47 (1), 63-70. http://dx.doi.org/10.1590/S151689132004000100009

Maity, T. and Raju, P.S. (2015). Development of shelf stable tomato rasam paste using hurdle technology. International Food Research Journal, 22(1), 171177. http://ifrj.upm.edu.my/22\%20(01)\%202015/ (25).pdf

Olaniran, A.F., Abiose, S.H. and Adeniran, A.H. (2015). Biopreservative effect of ginger (Zingiber Officinale) and garlic powder (Allium Sativum) on tomato paste. Journal of Food Safety, 35(4), 440-452. https:// doi.org/10.1111/jfs.12193

Padovani, R.M., Lima, D.M., Colugnati, F.A.B. and Rodriguez-Amaya, D.B. (2007). Comparison of proximate, mineral and vitamin composition of common Brazilian and US foods. Journal of Food Composition and Analysis, 20(8), 733-738. https:// doi.org/10.1016/j.jfca.2007.03.006

Sit, N., Misra, S., Baruah, D., Badwaik, L.S. and Deka, S.C. (2014). Physicochemical properties of taro and maize starch and their effect on texture, colour and sensory quality of tomato ketchup. Starch/Stärke, 66 (3-4), 294-302. https://doi.org/10.1002/ star.201300120

Villari, P., Costabile, P., Fasanaro, G., De Sio, F., Laratta, B., Pirone, G. and Castaldo, D. (1994). Quality loss of double concentrated tomato paste: Evolution of the microbial flora and main analytical parameters during storage at different temperatures. Journal of Food Processing and Preservation, 18(5), 369-387. https://doi.org/10.1111/j.17454549.1994.tb00260.x

WFP. (2011). World Food Programme, Technical Specifications for Tomato paste. Retrieved on August 21, 2020 from: https://documents.wfp.org/ stellent/groups/public/documents/ manual_guide_proced/wfp251120.pdf

Yang, L., Zhou, Y., Wu, Y., Meng, X., Jiang, Y., Zhang, H. and Wang, H. (2016). Preparation and physicochemical properties of three types of modified glutinous rice starches. Carbohydrate Polymers, 137, 305-313, https://doi.org/10.1016/ j.carbpol.2015.10.065

Ye, L., Wang, C., Wang, S., Zhou, S. and Liu, X. (2016). Thermal and rheological properties of brown flour from Indica rice. Journal of Cereal Science, 70, 270 -274. https://doi.org/10.1016/j.jcs.2016.07.007

Yildiz, H. and Baysal, T. (2007). Color and lycopene content of tomato puree affected by electroplasmolysis. International Journal of Food Properties, 10(3), 489-495. https:// doi.org/10.1080/10942910600909063 